\title{
Integration of Biological Control Agents and Systemic Acquired Resistance Inducers Against Bacterial Spot on Tomato
}

A. Obradovic and J. B. Jones, Department of Plant Pathology, University of Florida, Gainesville 32611; M. T. Momol and S. M. Olson, North Florida Research and Education Center, University of Florida, IFAS, Quincy 32351; L. E. Jackson, OmniLytics Inc., Salt Lake City, UT 84116; B. Balogh, Department of Plant Pathology, University of Florida, Gainesville; K. Guven, Anadolu University, Department of Biology, Yunus Emre Campus, 26470 Eskisehir, Turkey; and F. B. Iriarte, Department of Plant Pathology, University of Florida, Gainesville

\begin{abstract}
Obradovic, A., Jones, J. B., Momol, M. T., Olson, S. M., Jackson, L. E., Balogh, B., Guven, K., and Iriarte, F. B. 2005. Integration of biological control agents and systemic acquired resistance inducers against bacterial spot on tomato. Plant Dis. 89:712-716.

Two strains of plant growth-promoting rhizobacteria, two systemic acquired resistance inducers (harpin and acibenzolar-S-methyl), host-specific unformulated bacteriophages, and two antagonistic bacteria were evaluated for control of tomato bacterial spot incited by Xanthomonas campestris pv. vesicatoria in greenhouse experiments. Untreated plants and plants treated with copper hydroxide were used as controls. The plant growth-promoting rhizobacteria or a tap water control were applied as a drench to the potting mix containing the seedlings, while the other treatments were applied to the foliage using a handheld sprayer. The plant growth-promoting rhizobacteria strains, when applied alone or in combination with other treatments, had no significant effect on bacterial spot intensity. Messenger and the antagonistic bacterial strains, when applied alone, had negligible effects on disease intensity. Unformulated phage or copper bactericide applications were inconsistent in performance under greenhouse conditions against bacterial spot. Although acibenzolar-S-methyl completely prevented occurrence of typical symptoms of the disease, necrotic spots typical of a hypersensitive reaction (HR) were observed on plants treated with acibenzolar-S-methyl alone. Electrolyte leakage and population dynamics experiments confirmed that acibenzolar-S-methyl-treated plants responded to inoculation by eliciting an HR. Application of bacteriophages in combination with acibenzolar-S-methyl suppressed a visible HR and provided excellent disease control. Although we were unable to quantify populations of the bacterium on the leaf surface, indirectly we determined that bacteriophages specific to the target bacterium reduced populations of a tomato race 3 strain of the pathogen on the leaf surface of acibenzolar-S-methyl-treated plants to levels that did not induce a visible HR. Integrated use of acibenzolar- $S$-methyl and phages may complement each other as an alternative management strategy against bacterial spot on tomato.
\end{abstract}

Additional keywords: integrated management, SAR inducers

Bacterial spot caused by Xanthomonas campestris pv. vesicatoria (Doidge) Dye is a serious threat in commercial field and greenhouse tomato (Lycopersicon esculentum Mill.) production (12). Disease management based on cultural practices, chemical application, and use of resistant cultivars is mediocre, especially in tropical and subtropical regions where environ-

Corresponding author: M. T. Momol

E-mail: tmomol@ufl.edu

This research was supported by the Florida Agricultural Experiment Station and approved for publication as Journal Series No. R-09297, and by the United States Department of Agriculture (USDA) Southern Region IPM (J. B. Jones, M. T. Momol, and S. M. Olson, USDA 00-34103-9094) and USDA T-STAR (J. B. Jones, M. T. Momol, and S. M. Olson, USDA 2002-34135-12348).

Accepted for publication 26 February 2005.

DOI: 10.1094/PD-89-0712

(C) 2005 The American Phytopathological Society mental conditions favor infection and disease development. Due to its adaptability and population diversity, the pathogen frequently overcomes all of these currently used disease control strategies $(5,10,11$, 13,18).

As a result of poor disease control and concern about excessive use of pesticides, research on disease management strategies was directed toward identifying alternative methods for tomato bacterial spot management. New approaches have placed greater reliance on biological technologies that could be used effectively in integrated disease management programs $(6,9,21)$. Use of bacterial biocontrol agents $(2,8,14,15,19,20)$, bacteriophages $(1,4)$, and compounds that induce systemic acquired resistance (SAR) in the plant $(3,12,17)$ have been reported as effective alternative tools for disease control. Among the products tested in this study, Actigard, Messenger, and bacteriophages Agriphage are available commercially in the United States. In north Florida, Acti- gard is used routinely against bacterial spot on fieldgrown fresh-market tomato. AgriPhage has an experimental use permit and a United States federal label is expected soon. Messenger has a federal label that excludes California and Colorado. It is not used widely on tomato against bacterial spot in north Florida. These products were evaluated in this study at labeled rates.

In an effort to develop more sustainable and integrated strategies for reducing bacterial spot severity on tomato, we investigated various combinations of biocontrol agents, including plant growth-promoting rhizobacteria (PGPR), bacterial antagonists, unformulated bacteriophages (phages) that infect $X$. campestris pv. vesicatoria, and SAR inducers in greenhouse experiments. Assays were conducted to understand the effect of phages on reducing a hypersensitive-like reaction observed on acibenzolarS-methyl (Actigard)-treated plants during this study.

\section{MATERIALS AND METHODS}

Bacterial strains. A copper-sensitive race T3 (91-118) strain and race T1 (91106) strain of $X$. campestris pv. vesicatoria race were used. Two bacterial strains recognized as PGPR, Bacillus pumilus B122 (originally designated as SE34) and Pseudomonas fluorescens B130 (Obtained from J. Kloepper, Auburn University), originally designated as 89B61) (8), and two strains with potential antagonistic activity, $P$. syringae Cit7 and P. putida B56 (obtained from M. Wilson, previously at Auburn University) (20), were used as biocontrol agents in this study. The strains were stored in $30 \%$ glycerol at $-80^{\circ} \mathrm{C}$. Before use, they were grown in nutrient broth on a rotary shaker at $28^{\circ} \mathrm{C}$ for $24 \mathrm{~h}$. Bacteria were harvested by centrifugation and resuspended in sterile tap water. Concentration was determined by measuring optical density at $600 \mathrm{~nm}\left(\mathrm{OD}_{600}=0.3\right)$ using a spectrophotometer. It was adjusted to be approximately $10^{8} \mathrm{CFU} / \mathrm{ml}$.

Plant material. Tomato cv. Florida 47 was used in experiments $\mathrm{A}, \mathrm{B}, \mathrm{C}$, and $\mathrm{D}$, and cv. Bonny Best was used in a fifth experiment to determine whether the response in Actigard-treated plants was a hypersensitive reaction (HR). Plants were grown in $10-\mathrm{cm}$ pots containing soilless 
medium (Metro Mix 300, Marysville, $\mathrm{OH}$ ), watered daily, and fertilized two times with a soluble 20-20-20 (N-P-K) fertilizer (0.4 g/pot; Peter's Fertilizer Products, W. R. Grace \& Co., Fogelsville, PA) before reaching the four-leaf stage (approximately 6 weeks from sowing seed). They were inoculated by spraying a suspension $\left(10^{8}\right.$ $\mathrm{CFU} / \mathrm{ml}$ ) of $X$. campestris pv. vesicatoria T3 strain 91-118 with a handheld sprayer until runoff. Immediately after inoculation, plants were covered with plastic bags and placed in a growth chamber at $28^{\circ} \mathrm{C}$ with a $12 \mathrm{~h}$ photoperiod for 36 to $48 \mathrm{~h}$. The bags then were removed and the plants were transferred to a greenhouse bench.

Comparison of selected combinations of PGPRs, SAR inducers, foliar bacterial antagonists, and phages on bacterial spot intensity. Experiment $A$. Two PGPR strains, B. pumilus $\mathrm{B} 122$ and $P$. fluorescens B130, applied alone or in combination with foliar applications of harpin protein (Messenger; Eden Bioscience Corp., Bothell, WA), acibenzolar-S-methyl (Actigard 50WG; Syngenta Crop Protection Inc., Greensborough, NC), unformulated bacteriophage (phage) mixture (Agriphage; OmniLytics Inc., Salt Lake City, UT), or a suspension of one of the antagonists $(P$. syringae $\mathrm{Cit} 7$ or $P$. putida $\mathrm{B} 56)$ were compared for control of tomato bacterial spot disease in the greenhouse (Table 1). They also were compared with the untreated control (UTC) and plants treated with a grower standard bactericide (copper hydroxide; Kocide 2000; Griffin Corp., Valdosta, GA). The PGPR (B122 or B130) suspension or a tap water control was drenched in a potting mix (50 ml/pot), while foliar treatments were applied with a handheld sprayer until run-off at concentrations indicated in Table 1. Messenger and Agriphage treatments were prepared with nonchlorinated water, as recommended by the manufacturers. The phage mixture contained six different bacteriophage strains specific to $X$. campestris pv. vesicatoria race T3. All treatment combinations were applied before plants reached the four-leaf stage.

Experiment $B$. The effect of PGPRs and combinations of foliar treatments, including SAR inducers (Messenger and Actigard), antagonistic bacteria (Cit7 and B56), and phages for controlling bacterial spot of tomato was investigated (Table 2). The application schedule and treatment concentration remained the same as in Table 1 with the exception of Messenger, which was applied at the same time as Actigard.

Interaction of SAR inducers and phage. Experiment $C$. The SAR inducers Actigard and Messenger were compared in various combinations with and without phages to determine their potential for use in the integrated management of bacterial spot of tomato (Table 3). The first SAR inducer (Actigard and Messenger) applica- tion was a drench $(50 \mathrm{ml} / \mathrm{pot}) 19$ days before inoculation (at the four-leaf stage), followed by two foliar applications 12 and 5 days before inoculation. The concentrations of Actigard, Messenger, Agriphage, and copper hydroxide were the same as specified earlier (Table 1).

Experiment D. Tomato plants were grown to the four-leaf stage and then treated with Actigard three times as de-

Table 1. Application timing and concentrations of treatments tested in tomato bacterial spot experiments A, B, C (except timing), and D

\begin{tabular}{|c|c|c|c|}
\hline \multirow[b]{2}{*}{ Treatments } & \multicolumn{2}{|c|}{ Application timing ${ }^{y}$} & \multirow[b]{2}{*}{ Concentration } \\
\hline & First & Second & \\
\hline \multicolumn{4}{|l|}{$\begin{array}{l}\text { Drench treatments } \\
\text {. }\end{array}$} \\
\hline \multicolumn{4}{|l|}{ Water } \\
\hline Bacillus pumilus $\mathrm{B} 122$ & $14 \mathrm{~d}$ & $7 \mathrm{~d}$ & $10^{8} \mathrm{CFU} / \mathrm{ml}$ \\
\hline Pseudomonas fluorescens B130 & $14 \mathrm{~d}$ & $7 \mathrm{~d}$ & $10^{8} \mathrm{CFU} / \mathrm{ml}$ \\
\hline \multicolumn{4}{|l|}{ Foliar treatments } \\
\hline Harpin (Messenger) & $7 \mathrm{~d}$ & $1 \mathrm{~d}$ & $0.0018 \% \mathrm{z}$ \\
\hline Acibenzolar-S- Methyl (Actigard) & $9 \mathrm{~d}$ & $4 \mathrm{~d}$ & $0.003 \%{ }^{z}$ \\
\hline P. syringae Cit7 & $7 \mathrm{~d}$ & $2 \mathrm{~h}$ & $10^{8} \mathrm{CFU} / \mathrm{ml}$ \\
\hline P. putida $\mathrm{B} 56$ & $7 \mathrm{~d}$ & $2 \mathrm{~h}$ & $10^{8} \mathrm{CFU} / \mathrm{ml}$ \\
\hline Bacteriophage (Agriphage) & $\ldots$ & $2 \mathrm{~h}$ & $1 \% \mathrm{vol} / \mathrm{vol}$ \\
\hline Copper hydroxide (Kocide 2000) & $\ldots$ & $1 \mathrm{~d}$ & $0.135 \%{ }^{\mathrm{z}}$ \\
\hline Untreated control & $\ldots$ & $\ldots$ & $\ldots$ \\
\hline
\end{tabular}

${ }^{\mathrm{y}}$ Timing of treatment application before inoculation; $\mathrm{d}=$ days and $\mathrm{h}=$ hours.

${ }^{\mathrm{z}}$ Concentration of active ingredient.

Table 2. Effect of acibenzolar-S-methyl (Actigard), harpin (Messenger), bacterial antagonists and unformulated phage (Agriphage) applied alone or in combination on bacterial spot intensity (experiment B)

\begin{tabular}{lc}
\hline Foliar treatments $^{\mathbf{y}}$ & $\mathbf{L o g}_{\mathbf{1 0}}\left(\mathbf{l e s i o n s + 1 )} / \mathbf{p l a n t}^{\mathbf{z}}\right.$ \\
\hline Untreated control & $1.90 \mathrm{a}$ \\
Copper hydroxide & $1.09 \mathrm{def}$ \\
Harpin & $1.81 \mathrm{a}$ \\
Harpin + B56 & $1.67 \mathrm{ab}$ \\
Harpin + B56 + Phage & $1.43 \mathrm{bc}$ \\
Harpin + Cit7 & $1.65 \mathrm{ab}$ \\
Harpin + Cit7 + Phage & $1.24 \mathrm{cde}$ \\
Harpin + Phage & $1.13 \mathrm{~cd}$ \\
Acibenzolar-S-methyl & $1.29 \mathrm{fg}$ \\
Acibenzolar-S-methyl + B56 & $0.92 \mathrm{efg}$ \\
Acibenzolar-S-methyl + B56 + Phage & $0.95 \mathrm{gh}$ \\
Acibenzolar-S-methyl + Cit7 & $0.77 \mathrm{~h}$ \\
Acibenzolar-S-methyl + Cit7 + Phage & $0.27 \mathrm{~h}$ \\
Acibenzolar-S-methyl + Phage & $0.27 \mathrm{~h}$ \\
Phage & $1.39 \mathrm{bc}$ \\
Cit7 & $1.85 \mathrm{a}$ \\
B56 & $1.68 \mathrm{ab}$ \\
\hline
\end{tabular}

${ }^{\mathrm{y}}$ For acibenzolar-S-methyl treatments, atypical necrotic spots were counted in addition to typical bacterial spots; Cit7 = Pseudomonas syringae $\mathrm{Cit} 7$; B56 = P. putida $\mathrm{B} 56$.

${ }^{\mathrm{z}}$ Values followed by different letters are significantly different ( $F$ was significant at $P=0.0001$ ) based on Waller-Duncan k-ratio $t$ test.

Table 3. Effect of harpin (Messenger), acibenzolar-S-methyl (Actigard), and phage (Agriphage) applications on bacterial spot intensity per plant in greenhouse experiment $\mathrm{C}$

\begin{tabular}{|c|c|c|c|}
\hline \multicolumn{3}{|c|}{ Treatment and applications ${ }^{y}$} & \multirow[b]{2}{*}{ Lesions $^{2}$} \\
\hline Drench $(19 \mathrm{~d})$ & First foliar (12 d) & Second foliar & \\
\hline \multirow{2}{*}{$\cdots$} & $\ldots$ & Untreated control & $2.62 \mathrm{a}$ \\
\hline & $\ldots$ & Copper hydroxide (1 d), Phage (2 h) & $2.57 \mathrm{a}$ \\
\hline Harpin & Harpin & Harpin $(5 \mathrm{~d})$ & $2.48 \mathrm{a}$ \\
\hline Harpin & Harpin & Harpin $(5 \mathrm{~d})$, Phage $(2 \mathrm{~h})$ & $1.93 \mathrm{~b}$ \\
\hline Harpin & Harpin & $\operatorname{ASM}(5 \mathrm{~d})$ & $1.40 \mathrm{c}$ \\
\hline Harpin & Harpin & ASM (5d), Phage ( $2 \mathrm{~h})$ & $1.73 \mathrm{~b}$ \\
\hline ASM & ASM & $\operatorname{ASM}(5 \mathrm{~d})$ & $0.0 \mathrm{~d}$ \\
\hline ASM & ASM & $\operatorname{ASM}(5 \mathrm{~d})$, Phage $(2 \mathrm{~h})$ & $0.0 \mathrm{~d}$ \\
\hline ASM & ASM & $\operatorname{Harpin}(5 \mathrm{~d})$ & $0.0 \mathrm{~d}$ \\
\hline ASM & ASM & $\operatorname{Harpin}(5 \mathrm{~d})$, Phage $(2 \mathrm{~h})$ & $0.0 \mathrm{~d}$ \\
\hline$\ldots$ & $\ldots$ & Phage $(2 \mathrm{~h})$ & $2.54 \mathrm{a}$ \\
\hline
\end{tabular}

${ }^{\mathrm{y}}$ Timing of treatment application before inoculation in parentheses; $\mathrm{d}=$ days and $\mathrm{h}=$ hours. ASM $=$ Acibenzolar-S-methyl.

${ }^{\mathrm{z}} \log _{10}$ (lesions +1$) /$ plant. Values followed by the same letter are not significantly different according to Waller-Duncan k-ratio $t$ test ( $F$ was significant at $P=0.0001$ ). 
scribed in experiment $\mathrm{C}$, or not treated. Seven days after the last application of Actigard, all plants were transferred to a growth chamber $\left(28^{\circ} \mathrm{C}, 12-\mathrm{h}\right.$ photoperiod) and the Actigard-treated plants were divided into two groups. Prior to inoculation, one group of Actigard-treated plants was sprayed with a mixture of $X$. campestris pv. vesicatoria race T3-specific bacteriophages ( $1 \% \mathrm{vol} / \mathrm{vol}$ in deionized water), resulting in approximately $10^{8}$ plaqueforming units (PFU)/ml; the second group was not treated with the bacteriophages. Plants not treated with Actigard also were sprayed with the phage suspension and were included as a control. Plants were maintained in the chamber for $2 \mathrm{~h}$ after treatment to dry the foliage. Four plants from each group were inoculated by spraying a suspension $\left(10^{8} \mathrm{CFU} / \mathrm{ml}\right)$ of a race $\mathrm{T} 1$ or race $\mathrm{T} 3$ strain of $X$. campestris pv. vesicatoria and then were covered with plastic bags to maintain high humidity. Plants treated with Actigard but not inoculated and those without any treatment but inoculated with the T3 strain were covered with plastic bags and used as controls. After $36 \mathrm{~h}$, all plants were uncovered and placed on a greenhouse bench. Intensity of bacterial spot was evaluated by counting the number of lesions per plant on inoculated leaves 1 and 2 weeks after inoculation. Plant reaction was determined visually (Table 4).

Table 4. Effect of acibenzolar-S-methyl (Actigard) and bacteriophages on development of atypical spots on tomato leaves inoculated with tomato race 1 (T1) and tomato race 3 (T3) strains of Xanthomonas campestris pv. vesicatoria in experiment $\mathrm{D}$

\begin{tabular}{lccc}
\hline Treatment & $\begin{array}{c}\text { Race used for } \\
\text { inoculation }\end{array}$ & Plant reaction $^{\mathbf{y}}$ & $\begin{array}{c}\mathbf{L o g}_{\mathbf{1 0}}(\mathbf{b a c t e r i a l ~ s p o t} \\
\text { lesions + 1)/plant }^{\mathbf{z}}\end{array}$ \\
\hline Untreated control & $\mathrm{T} 3$ & $\mathrm{~S}$ & $2.78 \mathrm{a}$ \\
T3-Phage & T1 & $\mathrm{S}$ & $2.42 \mathrm{~b}$ \\
T3-Phage & T3 & $\mathrm{S}$ & $1.87 \mathrm{c}$ \\
Actigard & T1 & HR1 & $0.0 \mathrm{~d}$ \\
Actigard, T3-Phage & T1 & HR1 & $0.0 \mathrm{~d}$ \\
Actigard & T3 & HR2 & $0.0 \mathrm{~d}$ \\
Actigard, T3-Phage & T3 & $\ldots$ & $0.0 \mathrm{~d}$ \\
Actigard & Water & $\ldots$ & $0.0 \mathrm{~d}$ \\
\hline
\end{tabular}

${ }^{\text {y }} \mathrm{S}=$ susceptible reaction and $\ldots=$ no reaction. Atypical lesions: HR1 $=$ pinpoint, brown necrotic spots and HR2 = large, irregular necrotic lesions.

${ }^{z}$ Only typical bacterial spot lesions counted. Values followed by the same letter are not significant according to Waller-Duncan k-ratio $t$ test $(F$ was significant at $P=0.0001)$.

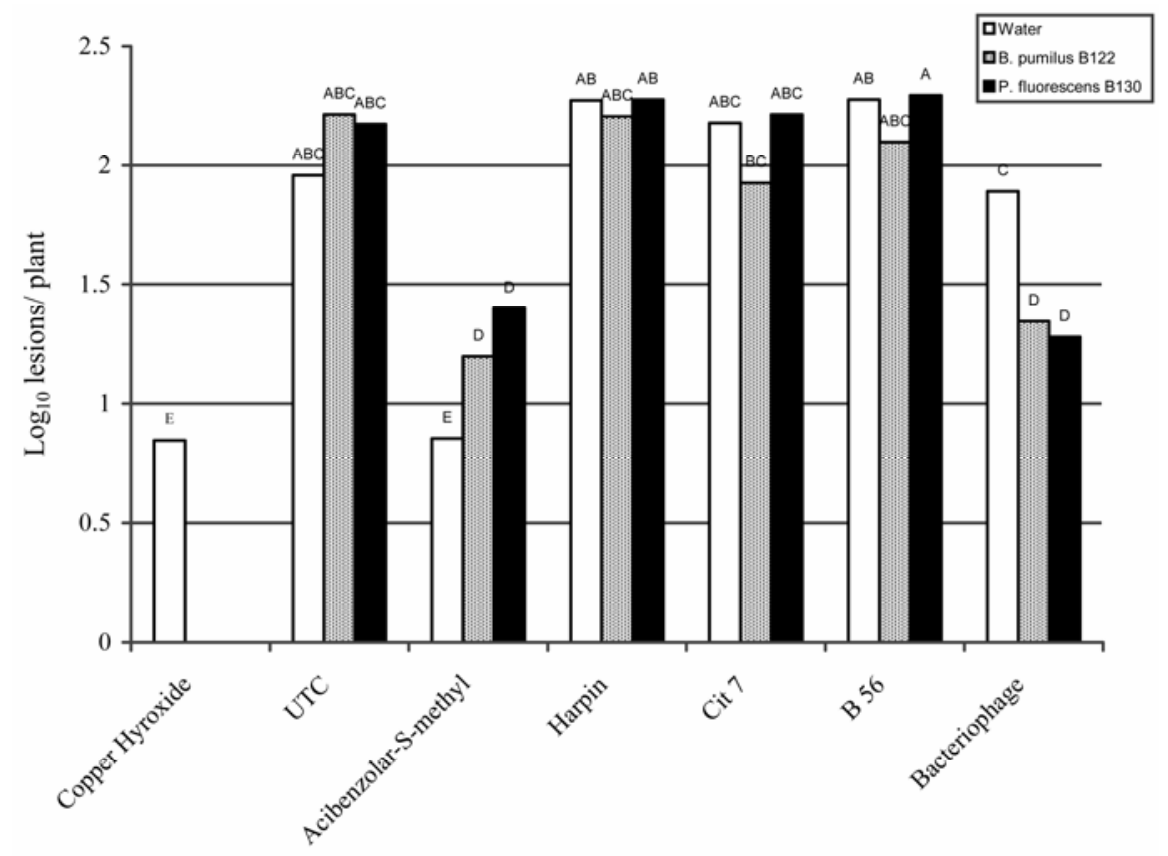

Treatments

Fig. 1. Effect of soil drenches with plant growth-promoting rhizobacteria (PGPR) (Bacillus pumilis B122 and Pseudomonas fluorescens B130) and foliar applications of acibenzolar-S-methyl (Actigard), harpin (Messenger), bacterial antagonists ( $P$. syringae $\mathrm{Cit7}$ and $P$. putida $\mathrm{B} 56$ ), and unformulated bacteriophages (Agriphage) on tomato bacterial spot intensity (experiment A). For Actigard treatment, atypical necrotic spots were counted to calculate disease intensity. The same letter above bars represents no significant difference between treatments according to Waller-Duncan k-ratio $t$ test ( $F$ was significant at $P=0.0001)$. Untreated control (UTC).
Assay for an HR induced by Actigard. Leaves of 6-week-old tomato plants cv. Bonny Best, untreated or sprayed two times with Actigard in a 7-day interval, were infiltrated with a suspension $\left(10^{7}\right.$ $\mathrm{CFU} / \mathrm{ml}$ ) of $X$. campestris pv. vesicatoria T3 strain 5 days after the last treatment. Starting immediately after inoculation and continuing every $24 \mathrm{~h}$ for 3 days, three leaflets from each treatment were collected, the infiltrated area was removed with a cork borer, and electrolyte leakage from the leaf tissue was measured as previously described (11). Pathogen populations were monitored in leaf tissue infiltrated with a suspension adjusted to $10^{5}$

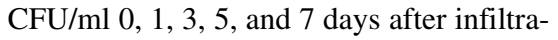
tion as previously described (11). This experiment was conducted twice.

Statistical analysis. For experiments A, B, C, and D, each treatment consisted of four replications with five plants per replicate arranged in a randomized complete block design. Each experiment was conducted once except when noted differently. Promising or SAR-phage combination treatments were conducted at least twice. Disease intensity was measured by counting the number of lesions per plant 1 and 2 weeks after inoculation. The data were transformed using $\log$ transformation $(y=$ $\left.\log _{10}[x+1]\right)$. Analysis of variance (ANOVA) was used. Treatment means were compared using the Waller-Duncan k-ratio $t$ test. Statistical analysis was performed with SAS (version 9.0; SAS Institute, Inc. Cary, NC).

\section{RESULTS}

Comparison of selected combinations of PGPRs, SAR inducers, foliar bacterial antagonists, and phages on bacterial spot intensity. Experiment $A$. PGPR treatments B. pumilus B122 and P. fluorescens B130, applied alone or in combination with foliar treatments, did not affect the number of bacterial spot lesions that developed on tomato leaves (Fig. 1), with the exception of the combination of either PGPR with phage, which was significantly better than phage alone. Application of Messenger, antagonistic bacteria $(P$. syringae Cit7 and $P$. putida $\mathrm{B} 56)$, and Agriphage did not reduce disease intensity. Actigard and copper hydroxide significantly reduced bacterial spot intensity. Small punctiform necrotic spots or lightbrown necrotic lesions, similar to an HR, were observed 3 days after inoculation on plants treated with Actigard. The spots did not increase in size or number during the 2-week evaluation period. No such symptoms occurred on new foliage of Actigardtreated plants or plants that received other treatments.

Experiment B. Drench application of PGPR strains did not reduce bacterial spot intensity compared with the water-treated control (data not shown). The combination of Actigard and Cit7 reduced bacterial spot 
intensity compared with Cit7 or Actigard alone (Table 2). Actigard, Agriphage, or copper hydroxide treatments alone significantly reduced the number of spots per plant compared with the untreated control. The same atypical symptoms described in experiment A were observed on plants treated with Actigard. However, their number was reduced by application of Actigard combined with Agriphage. Among all the treatments, the Actigard and Actigard in combination with Agriphage or Cit7 provided the best reduction of disease intensity (Table 2). Treatment with Messenger and the antagonistic strains (Cit 7 and B56, or their combination) had no effect on disease intensity.

Interaction of SAR inducers and Agriphage. Experiment $C$. No statistical difference in number of bacterial spot lesions was observed among plants treated with Messenger, Agriphage, copper, and the untreated control (Table 3). However, a significant reduction in disease intensity was achieved when Messenger, Actigard, and Agriphage all were applied to the same foliage, or combinations of two of the three were applied (Table 3).

Actigard was the most effective treatment in reducing bacterial spot intensity (Table 3). However, in this experiment, plants treated with Actigard developed more severe HR-like necrotic spots than in the previous experiment. Plant foliage was pale green with irregular chlorotic and necrotic lesions occurring 3 days after inoculation. These symptoms were most prominent on plants that received three applications of Actigard prior to inoculation, but were significantly reduced on plants treated with Agriphage. No such symptoms were observed on noninoculated plants receiving the same rate of Actigard.

Plants treated with two applications of Messenger followed by one application of Actigard had considerably less disease than in the untreated control plants (Table $3)$. Significantly fewer lesions were observed than on plants treated with Messenger alone or a combination Messenger and Agriphage.

Actigard-Agriphage interaction (experiment $D$ ). No typical bacterial spot symptoms were observed on Actigardtreated and inoculated plants (Table 4). However, pinpoint necrotic spots occurred on the Actigard-treated plants inoculated with either $X$. campestris pv. vesicatoria race $\mathrm{T} 1$ or $\mathrm{T} 3$ strains (Table 4). Pinpoint necrotic spots were observed on Actigardtreated plants following inoculation with the $\mathrm{T} 1$ strain, whereas larger, irregular spots occurred on Actigard-treated plants inoculated with the T3 strain. However, the intensity of the HR reaction induced by the T3 strain was eliminated on plants treated with a T3-specific phage. No typical disease symptoms were observed on the Actigard-treated plants (Table 4). However, pretreatment of the plants with the T3- specific phage did not prevent development of atypical symptoms on Actigardtreated plants or bacterial spot symptoms on plants inoculated with T1 strain. No changes were observed on the plants treated with Actigard but not challenged by the pathogen.

Evidence for an HR induced by Actigard. Tomato leaf tissue treated with Actigard collapsed $24 \mathrm{~h}$ after infiltration and became necrotic within the next $48 \mathrm{~h}$, resembling the hypersensitive type of plant reaction; whereas, on inoculated control plants, initial symptoms characteristic of a susceptible reaction occurred $48 \mathrm{~h}$ after infiltration. Watersoaked tissue on control plants collapsed 1 day later, and finally necrotized 4 days after inoculation. Visual observations of $\mathrm{HR}$ in Actigard-treated tissue were supported by increased speed of electrolyte leakage compared with the control (Fig. 2A); furthermore, bacterial populations in Actigard-treated tissue decreased 3 days after infiltration, whereas the populations in the inoculated control plants continued increasing (Fig. 2B).

\section{DISCUSSION}

As a result of the poor efficacy of copper compounds for bacterial spot and envi- ronmental concerns over intensive use of copper, there have been increased efforts to identify and implement alternative biological or environmentally low-risk approaches in disease management strategies (16). Recently, promising results have been published on suppressing plant pathogens by application of antagonistic microorganisms, PGPR, bacteriophages, and plant resistance activators $(1-4,7-9,12,14,15,17$, 19,20).

Adaptability and population diversity of the tomato pathogen $X$. campestris $\mathrm{pv}$. vesicatoria contributes to the limited success of available cultural practices and chemical products in tomato bacterial spot management, especially in tropical and subtropical regions where climatic conditions favor infection and disease development (12). Occurrence of bacterial strains resistant to streptomycin and fixed-copper bactericides reduces effectiveness of these routinely used products $(13,18)$. Racespecific host resistance may be ineffective due to variable pathogen populations $(10,11)$. As a result of low-efficacy crop protection methods for control of bacterial spot, considerable economic losses occur in tomato production every year. Recently, some biological methods were used suc-
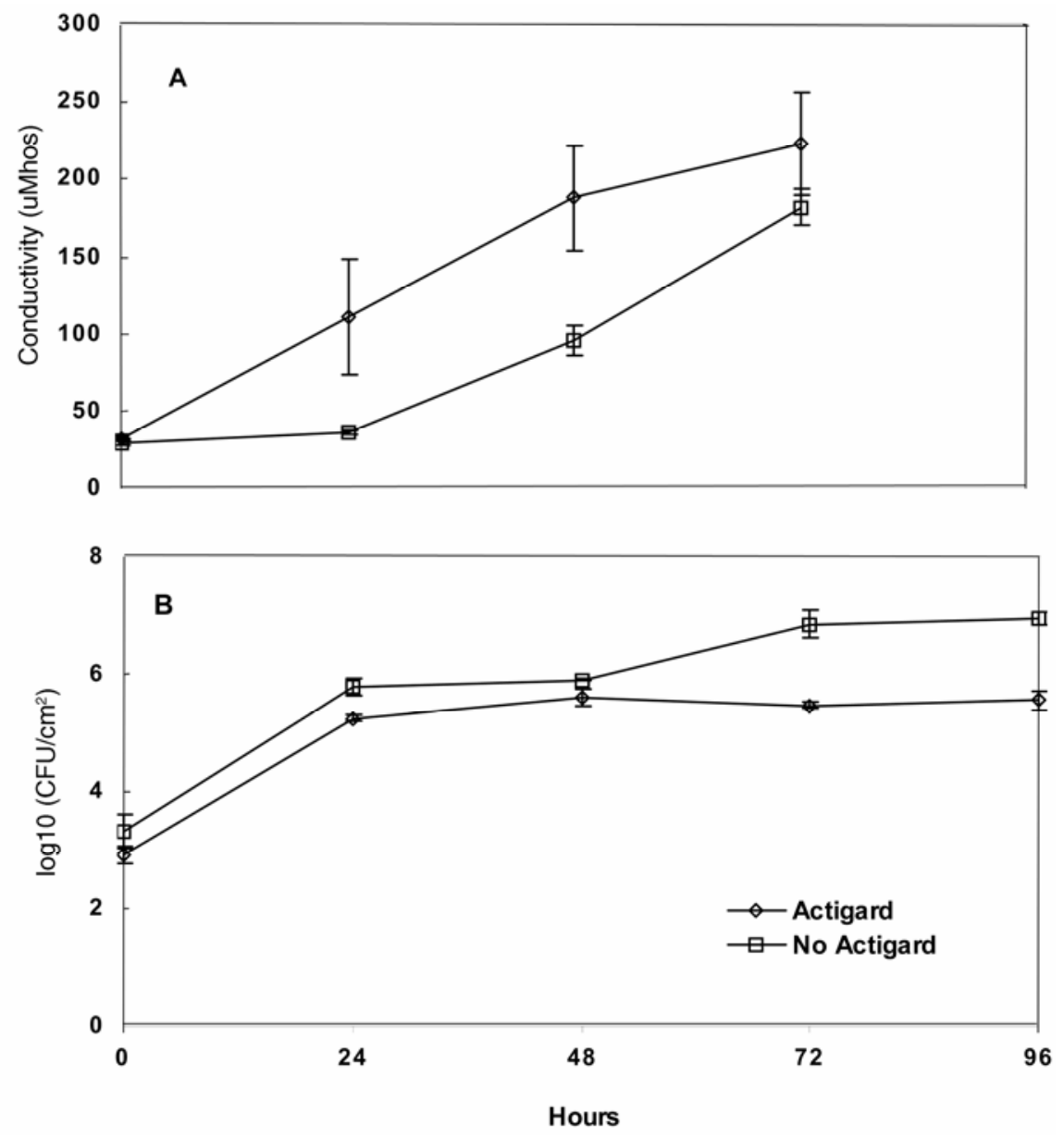

Fig. 2. Effect of foliar treatment with acibenzolar S-methyl (Actigard) on A, electrolyte leakage and $\mathbf{B}$, bacterial populations in tomato leaf tissue following infiltration with Xanthomonas campestris pv. vesicatoria at $10^{7} \mathrm{CFU} / \mathrm{ml}$. Error bars indicate the standard error. 
cessfully to control tomato bacterial diseases $(1,2,4,8,12,19,20)$. However, they were used mostly as single treatments. We integrated some of these practices, optimizing their benefits in control of tomato bacterial spot in the greenhouse to help to understand how to design more sustainable disease management strategies for tomato field production.

Unlike successful application of PGPR and antagonistic strains in control of bacterial speck of tomato $(8,19,20)$, in this study, the strains B. pumilus B122, P. fluorescens $\mathrm{B} 130, P$. syringae $\mathrm{Cit7}$, and $P$. putida B56 did not provide satisfactory control of tomato bacterial spot in the greenhouse. Perhaps the high inoculum concentration and greenhouse conditions highly favorable for disease development could have contributed to decreased competitive activity of these PGPR and antagonistic strains in these experiments.

The bacteriophage mixture (Agriphage) consisting of six host-range mutant (hmutant) bacteriophages, capable of attacking an extended range of $X$. campestris pv. vesicatoria strains, was used in the studies. Although a previous study proved the effectiveness of the bacteriophages in control of tomato bacterial spot (4), our experiments showed inconsistent performance of phage treatment under greenhouse conditions. A single application of unformulated phages used in this study probably contributed to this inconsistency. Balogh et al. (1) showed limited survival of unformulated phage in natural conditions and the importance of formulation to obtain higher efficacy.

The harpin protein, the active ingredient of Messenger, did not induce effective plant defense responses against $X$. campestris pv. vesicatoria, especially when it was applied alone. However, when Messenger was applied in combination with phage, bacterial spot intensity was significantly reduced.

Actigard effectively initiated plant defense mechanisms against $X$. campestris pv. vesicatoria and completely prevented the occurrence of typical symptoms of the disease under greenhouse conditions. However, pinpoint necrotic spots and irregular chlorotic and necrotic lesions (experiment $\mathrm{C}$ ) occurred on the foliage of Actigard-treated plants 3 days after inoculation. No further increase in size or number of lesions was observed, indicating that this compound induced HR of the plant against the pathogen, preventing the infection process. Infiltration of the $X$. campestris pv. vesicatoria suspension $\left(10^{7}\right.$ $\mathrm{CFU} / \mathrm{ml}$ ) into the intercellular spaces of leaflets resulted in tissue collapse in Actigard-treated plants after $48 \mathrm{~h}$; whereas, in the untreated plants, the collapse occurred 1 day later. The difference in plant reaction indicated activation of the defense mechanism (i.e., HR) in Actigard-treated plants. The internal $X$. campestris pv. vesicatoria populations in Actigard-treated leaves were significantly lower than in nontreated leaves and supported the induction being characteristic of an HR. Application of phage in combination with Actigard resulted in elimination of HR-type lesions. This effect may have resulted from the phage application decreasing the pathogen population on the leaf surface and concomitant reduction in ingress and intensity of plant defense reaction induced by Actigard. Thus, applications of Actigard in combination with phages would have provided for successful disease control with less foliage damage resulting from an HR. These results indicate that the integration of Actigard and Agriphage application represents an effective alternative for disease control and may serve as the base for a new tomato bacterial spot management strategy. Based on several field experiments conducted in Florida, Actigard applied every 14 days and formulated Agriphage applied twice a week before sunset provided similar or better control of tomato bacterial spot than copper plus mancozeb treatments (M. T. Momol, J. B. Jones, and S. M. Olson, unpublished data).

\section{ACKNOWLEDGMENTS}

We thank J. W. Kloepper for supplying the two PGPR bacterial strains.

\section{LITERATURE CITED}

1. Balogh, B., Jones, J. B., Momol, M. T., Olson, S. M., Obradovic, A., King, P., and Jackson, L. E. 2003. Improved efficacy of newly formulated bacteriophages for management of bacterial spot on tomato. Plant Dis. 87:949-954.

2. Campbell, H. L., M. Wilson, J. M. Byrne, J. B. Jones, D. Cuppels, and T. V. Suslow. 1997. Control of bacterial speck and spot of tomato with biological agents and CGA-245704. (Abstr.) Phytopathology 87:S14.

3. Csinos, A. S., Pappu, H. R., McPherson, R. M., and Stephenson, M. G. 2001. Management of Tomato spotted wilt virus in flue-cured tobacco with acibenzolar- $S$-methyl and imidacloprid. Plant Dis. 85:292-296.

4. Flaherty, J. E., Jones, J. B., Harbaugh, B. K., Somodi, G. C., and Jackson, L. E. 2000. Control of bacterial spot on tomato in the greenhouse and field with H-mutant bacteriophages. HortScience 35:882-884.

5. Gassmann, W., Dahlbeck, D., Chesnokova, O., Minsavage, G. V., Jones, J. B., and Staskawicz, B. J. 2000. Molecular evolution of virulence in natural field strains of Xanthomonas campestris pv. vesicatoria. J. Bacteriol. 182:70537059.

6. Hall, R. 1995. Challenges and prospects of integrated pest management. Pages 1-21 in Novel Approaches to Integrated Pest Management. R. Reuveni, ed. Lewis Publishers, CRC Press, Inc., Boca Raton, FL.

7. Inbar, M., Doostdar, H., Sonoda, R. M., Leibee, G. L., and Mayer, R. T. 1998. Elicitors of plant defensive systems reduce insect densities and disease incidence. J. Chem. Ecol. 24:135-149.

8. Ji, P., Kloepper, J. W., Wilson, M., and Campbell, H. L. 1996. Rhizobacterial-induced systemic resistance in tomato against bacterial speck. (Abstr.) Phytopathology 86:S50.

9. Ji, P., and Wilson, M. 2003. Enhancement of population size of a biological control agent and efficacy in control of bacterial speck of tomato through salicylate and ammonium sulfate amendments. Appl. Environ. Microbiol. 69:1290-1294.

10. Jones, J. B., Stall, R. E., and Bouzar, H. 1998. Diversity among xanthomonads pathogenic on pepper and tomato. Annu. Rev. Phytopathol. 36:41-58.

11. Jones, J. B., Stall, R. E., Scott, J. W., Somodi, G. C., Bouzar, H., and Hodge, N. C. 1995. A third tomato race of Xanthomonas campestris pv. vesicatoria. Plant Dis. 79:395-398.

12. Louws, F. J., Wilson, M., Campbell, H. L., Cuppels, D. A., Jones, J. B., Shoemaker, P. B., Sahin, F., and Miller, S. A. 2001. Field control of bacterial spot and bacterial speck of tomato using a plant activator. Plant Dis. 85:481-488.

13. Marco, G. M., and Stall, R. E. 1983. Control of bacterial spot of pepper initiated by strains of Xanthomonas campestris pv. vesicatoria that differ in sensitivity to copper. Plant Dis. 67:779-781.

14. Raupach, G. S., and Kloepper, J. W. 1998. Mixtures of plant growth-promoting rhizobacteria enhance biological control of multiple cucumber pathogens. Phytopathology 88:11581164.

15. Raupach, G. S., Liu, L., Murphy, J. F., Tuzun, S., and Kloepper, J. W. 1996. Induced systemic resistance in cucumber and tomato against cucumber mosaic cucumovirus using plant growth-promoting rhizobacteria (PGPR). Plant Dis. 80:891-894.

16. Reuveni, R. 1995. Novel Approaches to Integrated Pest Management. Lewis Publishers, Boca Raton, FL.

17. Romero, A. M., Kousik, C. S., and Ritchie, D. F. 2001. Resistance to bacterial spot in bell pepper induced by acibenzolar-S-methyl. Plant Dis. 85:189-194.

18. Stall, R. E., and Thayer, P. L. 1962. Streptomycin resistance of the bacterial spot pathogen and control with streptomycin. Plant Dis. Rep. 46:389-392.

19. Wilson, M., Campbell, H. L., Ji, P., Jones, J. B., and Cuppels, D. A. 2002. Biological control of bacterial speck of tomato under field conditions at several locations in North America. Phytopathology 92:1284-1292.

20. Wilson, M., Campbell, H. L., Jones, J. B., Suslow, T. V., and Cuppels, D. A. 1996. Biological control of bacterial speck of tomato. (Abstr.) Phytopathology 86:S49.

21. Wilson, M., Savka, M. A., Hwang, I., Farrand, S. K., and Lindow, S. E.. 1995. Altered epiphytic colonization of mannityl opineproducing transgenic tobacco plants by a mannityl opine-catabolizing strain of Pseudomonas syringae. Appl. Environ. Microbiol. 61:21512158 . 